\title{
Requirement for G proteins in insulin-like growth factor-I-induced growth of prostate cells
}

\author{
T Lyons-Darden and Y Daaka ${ }^{1}$ \\ Departments of Surgery and ${ }^{1}$ Pharmacology and Cancer Biology, Duke University Medical Center, Durham, North Carolina 27710, USA \\ (Requests for offprints should be addressed to Y Daaka, DUMC 2607, Duke University Medical Center, Durham, North Carolina 27710, USA; \\ Email: daaka001@mc.duke.edu)
}

\begin{abstract}
Elevated levels of IGF-I in the circulation are associated with increased risk for the development of prostate cancer in men, and transgenic expression of human IGF-I in mouse epithelial prostate cells results in spontaneous prostate tumorigenesis. Little, however, is known about the mechanisms involved in the IGF-I-regulated growth of prostate cells. Here, we have demonstrated that treatment with IGF-I induces the activation of the mitogenic extracellular signal-regulated kinase (ERK) pathway and the growth of human prostate cells. Stimulation with IGF-I also promoted the tyrosine phosphorylation of epidermal growth factor receptor (EGFR). Signal relay from IGF-I to ERK requires heterotrimeric G proteins and EGFR; inhibition of Gi/o protein activation by pertussis toxin, or EGFR by tyrphostin AG1478 obliterated the ability of IGF-I to promote ERK activation. Further, treatment with pertussis toxin inhibited the IGF-I-mediated prostate cell growth. These data demonstrated the requirement of heterotrimeric $G$ proteins in IGF-I-regulated prostate cell growth and suggest the potential utility of the $G$ proteins as effective drug targets to combat this common cancer.
\end{abstract}

Journal of Molecular Endocrinology (2004) 33, 165-173

\section{Introduction}

Prostate cancer represents the most common malignant transformation that occurs in men and is the second leading cause of male cancer deaths in the USA (Jemal et al. 2003). In 2003, it was estimated that 221000 new prostate cancer cases were diagnosed, and 28900 men died from the disease (Jemal et al. 2003). Prostate cancer is multifocal and it is commonly observed that the cancerous gland contains multiple independent tumors, suggesting heterogeneity of the disease (Bostwick et al. 1998). Regulatory mechanisms involved in the pathogenesis and progression of this common cancer are poorly understood. Since the work of Huggins \& Hodges (1941) androgens (mainly dihydrotestosterone) have been considered to be the primary growth factors for prostatic epithelial cells. However, the reality that the cancer progresses to an androgen-refractory state and the frequent development of prostate cancer in older men who have reduced serum levels of testosterone suggest that non-androgenic growth factors contribute to the pathologic growth of the prostate (Raj et al. 2002, Nelson et al. 2003).

Epidemiologic studies provide a strong positive association between serum insulin-like growth factor-I (IGF-I) levels and prostate cancer risk (Chan et al. 1998). In transgenic mice, expression of human IGF-I in the basal epithelial cells of the prostate activates the IGF-I receptor and yields spontaneous neoplastic growth in prostate epithelium (DiGiovanni et al. 2000). In vitro, stimulation with IGF-I induces human prostate cell growth and survival (Djavan et al. 2001). The IGF-I exerts its proliferative effects on target cells by activating its cognate receptor, IGF-IR. The IGF-IR is a plasma membrane-anchored protein tyrosine kinase that consists of two extracellular $\alpha$ subunits and two plasma membrane-spanning $\beta$ subunits. The intrinsic tyrosine kinase activity is contained within the intracellular domain of the $\beta$ subunits. Upon ligand binding, the IGF-IR $\beta$ subunits are cross-phosphorylated and phosphorylate adapter proteins, such as insulin receptor substrate (IRS), Src homologous and collagen (Shc), and 
Grb2-associated binder 1 (Gabl) (LeRoith 2003). It has been proposed that tyrosine-phosphorylated IRS and Shc proteins relay divergent intracellular signals leading to cell survival and proliferation respectively. The IGF-I-induced cell survival is thought to occur via activation of the IRS/ phosphatidyl inositol 3-kinase/Akt pathway (Franke et al. 1997), whereas cell proliferation may proceed via the Shc/Grb2-Sos/Ras/extracellular signalregulated kinases 1/2 (ERK) mitogen-activated protein (MAP) kinase pathway (Sasaoka et al. 1994).

Heterotrimeric guanosine triphosphate-binding proteins ( $\mathrm{G}$ proteins) are increasingly recognized as critical regulators of prostate cancer cell growth (Daaka 2002, Raj et al. 2002). Stimulation of certain endogenous $\mathrm{G}$ protein-coupled receptors (GPCRs) induces the growth of prostate cancer cells. In addition, inhibition of G-protein signaling attenuates growth of prostate cancer cells both in vitro (Kue \& Daaka 2000) and in vivo (Bookout et al. 2003). Heterotrimeric G proteins are activated following stimulation of plasma membraneanchored GPCRs to yield the signal transducers G $\alpha$-GTP and G $\beta \gamma$ subunits. Recent evidence has demonstrated that heterotrimeric $\mathrm{G}$ proteins can also become activated by other mechanisms, including the binding to activators of $\mathrm{G}$ proteins (Blumer \& Lanier 2003), as well as in response to stimulating bona fide receptor tyrosine kinases (Yang et al. 1993, Zeng et al. 2002). Here, we studied the IGF-I-regulated mitogenic signaling and growth of prostate cells with special emphasis on $\mathrm{G}$ proteins. We have shown that IGF-I promotes the epidermal growth factor receptor (EGFR)- and Gi/o-dependent activation of ERK. We also found that IGF-I induces growth of human prostate cells via a mechanism that utilizes $\mathrm{Gi} /$ o proteins.

\section{Materials and methods}

\section{Materials}

The EGFR specific inhibitor AG1478, the MEK inhibitor PD098059, IGF-I, EGF, and pertussis toxin (PTX) were from Calbiochem (San Diego, CA, USA). The cell proliferation reagent WST-1 was obtained from Roche Molecular Biochemical (Indianapolis, IN, USA). Antibodies were obtained as follows: anti-phospho ERK from Cell Signaling (Beverley, MA, USA), anti-ERK 2 and anti-EGFR from Upstate Biotechnology (Charlottesville, VA,
USA), anti-IGF-IR from Oncogene Research (Tarrytown, NY, USA), anti-phosphotyrosine PY20H from Transduction Laboratories (San Diego, CA, USA), and anti-mouse and anti-rabbit horseradish peroxidase (HRP)-conjugated secondary antibodies from Jackson ImmunoResearch. Cell culture media and tissue culture supplements were obtained from Gibco-BRL. All other reagents were standard laboratory grade.

\section{Cell culture}

The P69SV40T cells were human non-tumorigenic prostate cells that are immortalized by transformation with the large $\mathrm{T}$ antigen of simian virus 40 (SV40), and were the kind gift of Dr J L Ware (Plymate et al. 1996). DU145 cells are human tumorigenic, androgen-independent prostate cancer cells, and were obtained from the American Type Culture Collection (Manassas, VA, USA). The P69SV40T cells were maintained in RPMI 1640 culture medium supplemented with $2 \mathrm{mM}$ L-glutamine, $5 \%$ fetal bovine serum (FBS), $5 \mu \mathrm{g} / \mathrm{ml}$ insulin, $5 \mu \mathrm{g} / \mathrm{ml}$ transferrin, $5 \mathrm{ng} / \mathrm{ml}$ selenious acid, $1 \mu \mathrm{M}$ dexamethasone, and $50 \mu \mathrm{g} / \mathrm{ml}$ gentamicin. Starvation medium used for these cells consisted of only L-glutamine and dexamethasone. The DU145 cells were maintained in RPMI 1640 culture medium supplemented with $2 \mathrm{mM}$ L-glutamine, $10 \% \mathrm{FBS}, 100 \mu \mathrm{g} / \mathrm{ml}$ penicillin-streptomycin, and $1 \mathrm{mM}$ Hepes, $\mathrm{pH} 7 \cdot 4$. Starvation medium used for these cells consisted of penicillin-streptomycin, Hepes buffer, and $0 \cdot 1 \%$ bovine serum albumin.

\section{Cell proliferation assay}

Cells were seeded at 2000 cells/well overnight in 96-well plates. The medium was replaced with serum-free medium overnight for DU145 cells, or for 3 days for P69SV40T cells. After the starvation period, cells were treated with the agonists indicated in the presence or absence of inhibitors. The Gi inhibitor PTX $(100 \mathrm{ng} / \mathrm{ml})$ and EGFR inhibitor tyrphostin AG1478 (250 nM) were added $18 \mathrm{~h}$ and $30 \mathrm{~min}$ respectively prior to treatment with agonist for 1 day for DU145 cells and for 3 days for P69SV40T cells. Cell proliferation was measured after $40 \mathrm{~min}$ incubation at $37^{\circ} \mathrm{C}$ with WST-1 reagent, which is used to measure mitochondrial enzymatic dehydrogenase activity of viable cells. An enzyme-linked immunosorbent 
assay (ELISA) reader was used to determine the absorbance at $\mathrm{A}_{450}$ (Barki-Harrington \& Daaka 2001). Absolute optical density was normalized to the absorbance of unstimulated cells in each plate and was expressed as percent of the control value.

\section{Immunoprecipitation and immunoblotting}

Cells were treated in serum-free medium with the agonist indicated at $37^{\circ} \mathrm{C}$ following preincubation with inhibitors as described in the Figure legends. After treatment, cells were placed on ice, washed twice with ice-cold phosphate-buffered saline, and lysed for $10 \mathrm{~min}$ with ice-cold RIPA buffer (150 mM NaCl, $50 \mathrm{mM}$ Tris-HCl, pH 8, $1 \mathrm{mM}$ EDTA, $0 \cdot 25 \%(\mathrm{w} / \mathrm{v})$ sodium deoxycholate, $0 \cdot 1 \%$ (v/v) Nonidet P-40, $1 \mathrm{mM} \mathrm{NaF}, 1 \mathrm{mM}$ sodium pyrophosphate, $100 \mu \mathrm{M} \mathrm{Na} \mathrm{VO}_{4}, 1 \mathrm{mM}$ phenylmethylsulfonyl fluoride, $10 \mu \mathrm{g} / \mathrm{ml}$ leupeptin, $10 \mu \mathrm{g} /$ aprotonin, and $0.7 \mu \mathrm{g} / \mathrm{ml}$ pepstatin). Cell lysates were briefly sonicated and clarified by centrifugation. Where indicated, a $30 \mu \mathrm{l}$ aliquot of whole cell lysate was mixed with an equal volume of Laemmli sample buffer (125 mM Tris-HCl, pH 6.8, 20\% glycerol, 4\% SDS, 10\% $\beta$-mercaptoethanol, and $0.005 \%$ bromophenol blue) and resolved by SDS-PAGE for determination of total protein expression and ERK phosphorylation by protein immunoblotting.

Immunoprecipitation of IGF-IR was performed using $1 \mu \mathrm{g} / \mathrm{ml}$ mouse anti-human IGF-IR $\alpha$ subunit monoclonal IgG. Immune complexes were collected using protein $\mathrm{G}$ plus/protein A agarose beads (Oncogene Science) following tumbling for 2-12 h at $4{ }^{\circ} \mathrm{C}$. Immunoprecipitates were resolved by SDS-PAGE and transferred to nitrocellulose filters for protein immunoblotting. Tyrosine phosphorylated proteins were detected by a 1:1000 dilution of HRP-conjugated anti-phosphotyrosine monoclonal antibody. Immunoblotting to detect EGFR and IGF-IR was performed using a 1:1000 dilution of each specific antibody with a 1:5000 dilution of the corresponding HRP-conjugated secondary antibody. Immunoblotted proteins were visualized using enzyme-linked chemiluminescence.

\section{ERK phosphorylation}

Cells were seeded in 6- or 12-well plates and incubated at $37^{\circ} \mathrm{C}$ overnight. The medium was replaced with serum-free medium overnight for
DU145 cells and 3 days for P69SV40T cells. Cells were treated for 2-60 min with the agonists indicated in the presence or absence of inhibitors. PTX (100 ng/ml) was added $18 \mathrm{~h}$, and AG1478 $(250 \mathrm{nM})$ and PD098059 $(1 \mu \mathrm{M})$ were added $30 \mathrm{~min}$ prior to stimulation with agonist. The treatment was terminated by direct cell lysis using Laemmli sample buffer. Cell lysates were boiled and resolved by SDS-PAGE. ERK phosphorylation was detected by protein immunoblotting using a 1:1000 dilution of rabbit polyclonal phospho-specific ERK IgG with HRP-conjugated goat anti-rabbit $\operatorname{IgG}$ as secondary antibody. Phosphorylated ERK proteins were visualized by chemiluminescence. Nitrocellulose membranes were stripped of immunoglobulin and re-probed using rabbit polyclonal anti-ERK $2 \mathrm{IgG}$ to confirm equal protein loading.

\section{Results}

The ability of IGF-I to induce proliferation of human prostate cells was assessed using the WST-1 reagent, which was used previously in our laboratory and yielded results similar to those obtained by actual counting of cells using a hemocytometer (Barki-Harrington \& Daaka 2001). Throughout these studies we utilized P69SV40T and DU145 as models for the study of nontumorigenic and tumorigenic human prostate cells respectively. Figure 1 shows that IGF-I could induce proliferation of the P69SV40T and DU145 cells in a dose-dependent manner, with maximal effects attained at 20-25 ng IGF-I/ml. The fold increase in IGF-I-induced growth of the P69SV40T cells observed was similar to that reported by others (Plymate et al. 1996). These data indicated that IGF-I is a potent proliferative agent for human prostate epithelial cells.

Cell growth can be achieved via the activation of several distinct intracellular signal transduction pathways. Malignant human prostate specimens express elevated levels of activated ERK, compared with benign samples (Gioeli et al. 1999), suggesting that activated ERK may contribute to pathologic growth of the prostate. We therefore compared the effect of IGF-I stimulation on ERK activation in the P69SV40T and DU145 prostate cells. Serum-starved cells were stimulated with IGF-I and examined for their content of phosphorylated ERK 


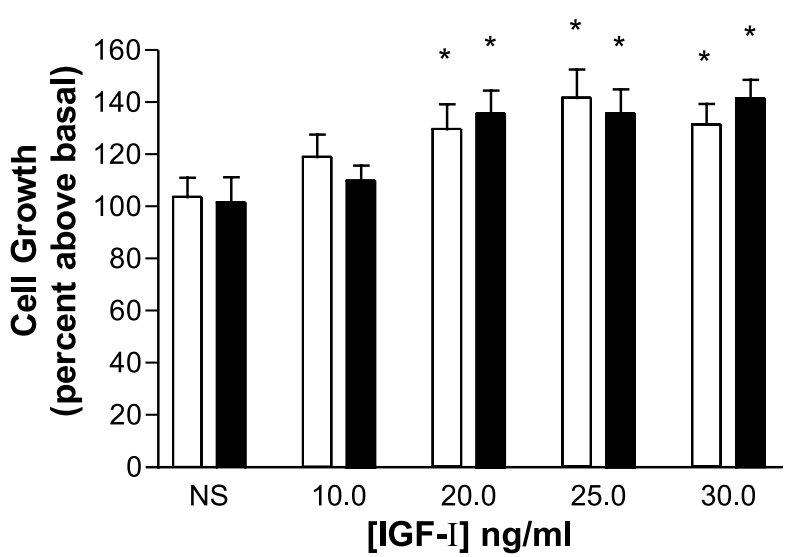

Figure 1 IGF-I promotes growth of human prostate cells. P69SV40T (open bars) and DU145 (solid bars) cells were seeded in 96-well plates overnight and incubated in serum-free medium. Cells were stimulated with the concentrations of IGF-I indicated. Cell proliferation reagent WST-1 was added to each sample for $30 \mathrm{~min}$ at $37^{\circ} \mathrm{C}$. Optical absorbance at $\mathrm{A}_{450}$ was determined using an ELISA reader. Values are presented as percent increase over baseline by dividing the average of absolute optical density in each treated group by the value obtained for unstimulated cells per plate. Each point represents the means \pm S.D. of values from seven independent experiments. ${ }^{\star} P<0.05$ versus control.

by immunoblotting. Stimulation with IGF-I promoted ERK phosphorylation, with maximal effects achieved after $5 \mathrm{~min}$ in the P69SV40T (Fig. 2A) and DU145 (Fig. 2B) cells. Dose-response experiments indicated that maximal ERK activation occurred at $10 \mathrm{ng} \mathrm{IGF}-\mathrm{I} / \mathrm{ml}$ for both cell types (Fig. 2C and D), which was in accordance with the IGF-I-induced cell proliferation assay (Fig. 1). In the case of P69SV40T cells, the magnitude of IGF-I-induced ERK phosphorylation was close to that achieved by the known mitogens EGF and lysophosphatidic acid (LPA), as well as serum (Fig. 2C). The amount of total ERK was determined by stripping the membranes of immunoglobulins and reblotting them for total ERK 2. Figure 2 (lower panels) shows that ERK expression was constant among the different samples, demonstrating that IGF-I caused an increase in ERK phosphorylation and not ERK expression.

Stimulation with IGF-I induced the tyrosine autophosphorylation of IGF-IR, which forms a scaffold for the recruitment of adapter proteins necessary for signal transduction. Figure 3 shows that IGF-I treatment of the P69SV40T cells promoted the tyrosine phosphorylation of immunoprecipitated IGF-IR in a time-dependent manner with maximal signal achieved between 5 and $7 \mathrm{~min}$ after stimulation. Interestingly, IGF-IR immunoprecipitates also contained a tyrosine phosphorylated protein that migrated to an apparent molecular mass of $180 \mathrm{kDa}$ (Fig. 3, shown by asterisk in upper panel). Immunoblotting experiments revealed that the IGF-IR-associated and tyrosine phosphorylated protein was EGFR (Fig. 3, middle panel). We also showed that stimulation of the DU145 cells with IGF-I induced complex formation between IGF-IR and EGFR (data not shown). Together, these results demonstrated that stimulation with IGF-I induces the formation of a heteroreceptor complex made of activated IGF-IR and EGFR in human prostate cells. Distinctly, direct stimulation with EGF did not lead to the tyrosine phosphorylation of IGF-IR or formation of IGF-IR-EGFR complexes (Fig. 3).

To determine whether the IGF-I-induced phosphorylation of EGFR is functionally relevant to IGF-I-regulated cell signaling, we assayed the effect of the EGFR specific inhibitor tyrphostin AG1478 on IGF-I-stimulated ERK phosphorylation. The data showed that treatment of the DU145 (Fig. 4A) and P69SV40T (Fig. 4G) cells with AG1478 completely abrogated the IGF-I-induced ERK phosphorylation. Specificity of AG1478 was verified by showing that it had no effect on the IGF-I-mediated tyrosine phosphorylation of IGF-IR, in accordance with previous results (Kue et al. 2002). As expected, the EGF-induced ERK phosphorylation was inhibited by AG1478 in both cell types (Fig. 4A and $\mathrm{G}$ ), and the IGF-I- and EGF-induced ERK phosphorylation was abrogated by the MAP kinase/ERK kinase (MEK) inhibitor PD098059 (Fig. 4A and B). Together, these data demonstrated the existence of an IGF$\mathrm{IR} \rightarrow \mathrm{EGFR} \rightarrow \mathrm{MEK} \rightarrow \mathrm{ERK}$ signal transduction cascade in human prostate cells.

These data showed that stimulation with IGF-I induces the tyrosine phosphorylation of EGFR (Fig. 3), which constitutes a necessary link between activated IGF-IR and mitogenic ERK (Fig. 4). We recently obtained similar data in response to direct stimulation of G protein-coupled LPA (Kue et al. 2002) and bradykinin (Barki-Harrington \& Daaka 2001, Barki-Harrington et al. 2003) receptors, which transduce their signals via activation of 
A

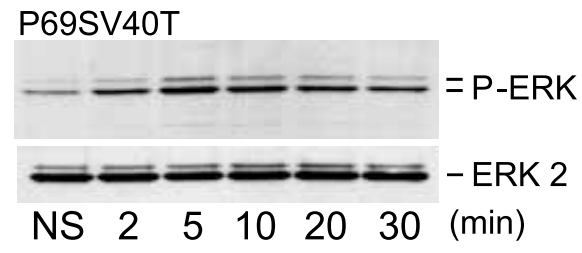

B

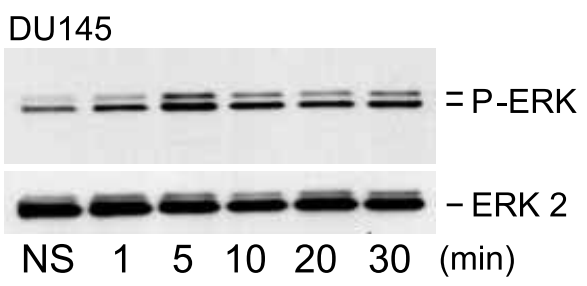

C

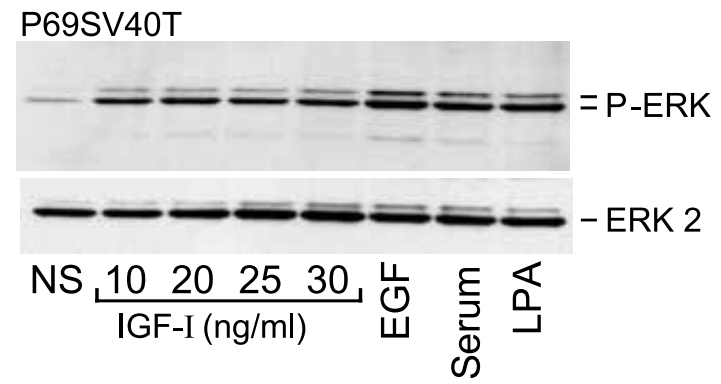

D

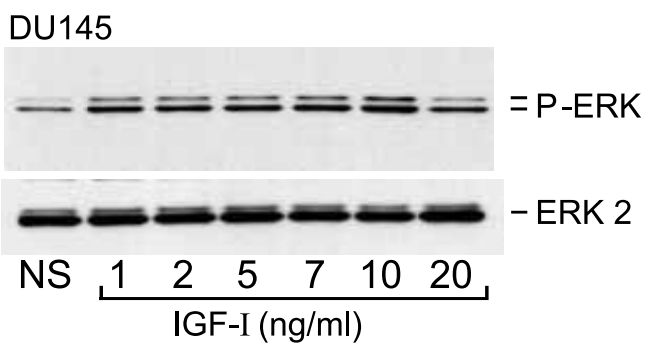

Figure 2 IGF-I activates ERK pathway in non-tumorigenic and tumorigenic human prostate cells. IGF-I-induced ERK activation is time-dependent. (A) P69SV40T and (B) DU145 cells were seeded in 12-well plates and incubated in serum-free medium prior to stimulation with IGF-I $(20 \mathrm{ng} / \mathrm{ml})$ for the time indicated. Cell monolayers were lysed with Laemmli sample buffer and lysates separated on 4-20\% SDS-PAGE. Proteins were transferred to nitrocellulose membranes and immunoblotted for phosphorylated ERK (P-ERK) or total ERK 2, as described. IGF-I-induced ERK activation is dose-dependent. Serum-starved (C) P69SV40T and (D) DU145 cells were stimulated with increasing concentrations of IGF-I for $5 \mathrm{~min}$ at $37^{\circ} \mathrm{C}$ and cell lysates analyzed for phosphorylated ERK and total ERK 2, as described. Data shown are representative of five independent experiments. NS, non-stimulated.

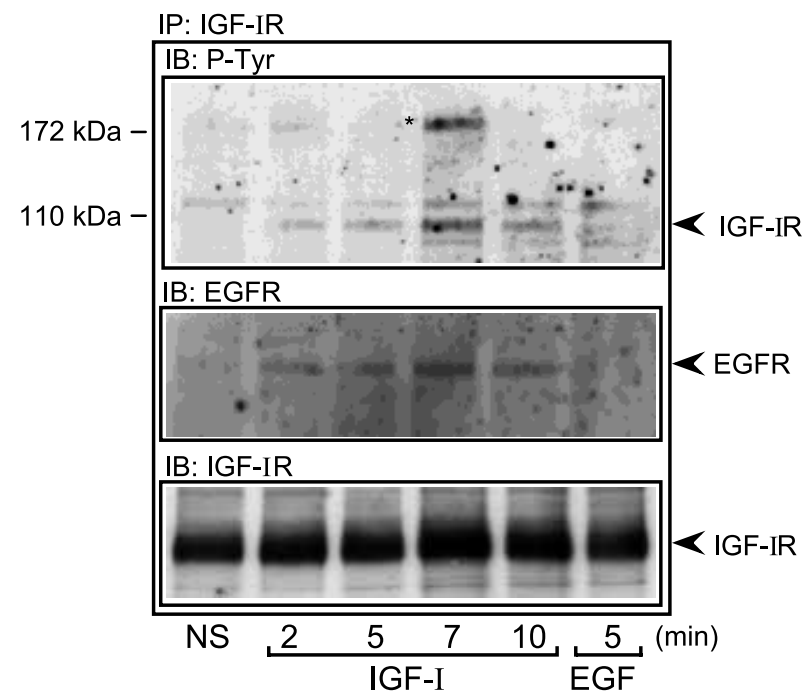

Figure 3 EGFR co-immunoprecipitates with activated IGF-IR. Serum-starved P69SV40T cells were stimulated with IGF-I $(20 \mathrm{ng} / \mathrm{ml})$ for the times indicated, followed by detergent lysis and immunoprecipitation of IGF-IR. Tyrosine phosphorylation was determined by protein immunoblotting with anti-phosphotyrosine IgG. Expression of EGFR and IGF-IR was determined by sequential stripping of the nitrocellulose membrane of immunoglobulins and reprobing it using anti-EGFR and anti-IGF-IR antibodies. NS, non-stimulated; IP, immunoprecipitation; IB, immunoblotting; *indicates co-immunoprecipitated tyrosine-phosphorylated protein.

heterotrimeric $\mathrm{G}$ proteins. We therefore tested whether $G$ proteins play a role in the IGF-Iregulated ERK phosphorylation in the prostate cells. Treatment of P69SV40T cells with PTX obliterated the IGF-I-induced ERK phosphorylation (Fig. 4C). PTX also reduced, albeit to a lesser extent, the IGF-I-mediated ERK phosphorylation in the DU145 cells (Fig. 4B), but had no effect on the EGF-mediated activation of ERK, consistent with previous results (Kue \& Daaka 2000). The results of three independent experiments demonstrated the inhibitory effects of PTX and AG1478 on the IGF-I-mediated ERK phosphorylation in the DU145 (Fig. 4D) and P69SV40T (Fig. 4E) cells. These data demonstrated that IGF-I-regulated activation of ERK in human tumorigenic and non-tumorigenic prostate cells involves activated Gi/o proteins and EGFR.

The data available show that activation of ERK constitutes an important precursor to prostate cell growth (Guo et al. 2000, Barki-Harrington \& Daaka 2001), and our results demonstrated a role for Gi/o 
A

\section{DU145}

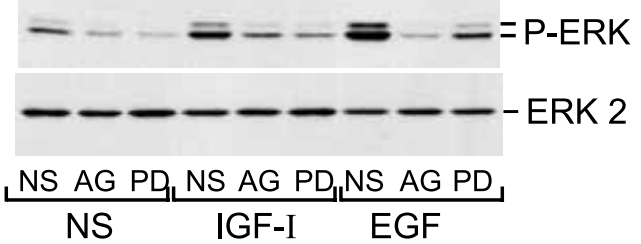

B

DU145

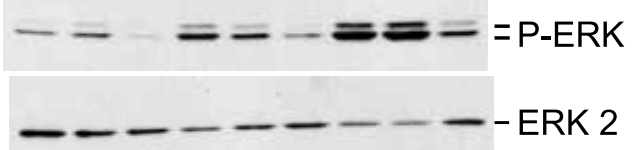

NS PTXPD, NS PTXPD,NS PTXPD,

NS IGF-I EGF

C

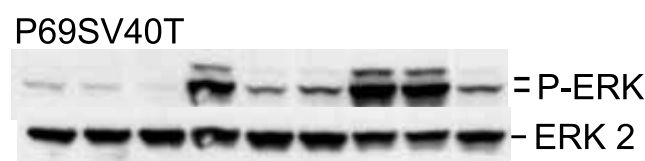

NS PTXAG NS PTXAGNS PTXAG,

NS IGF-I EGF
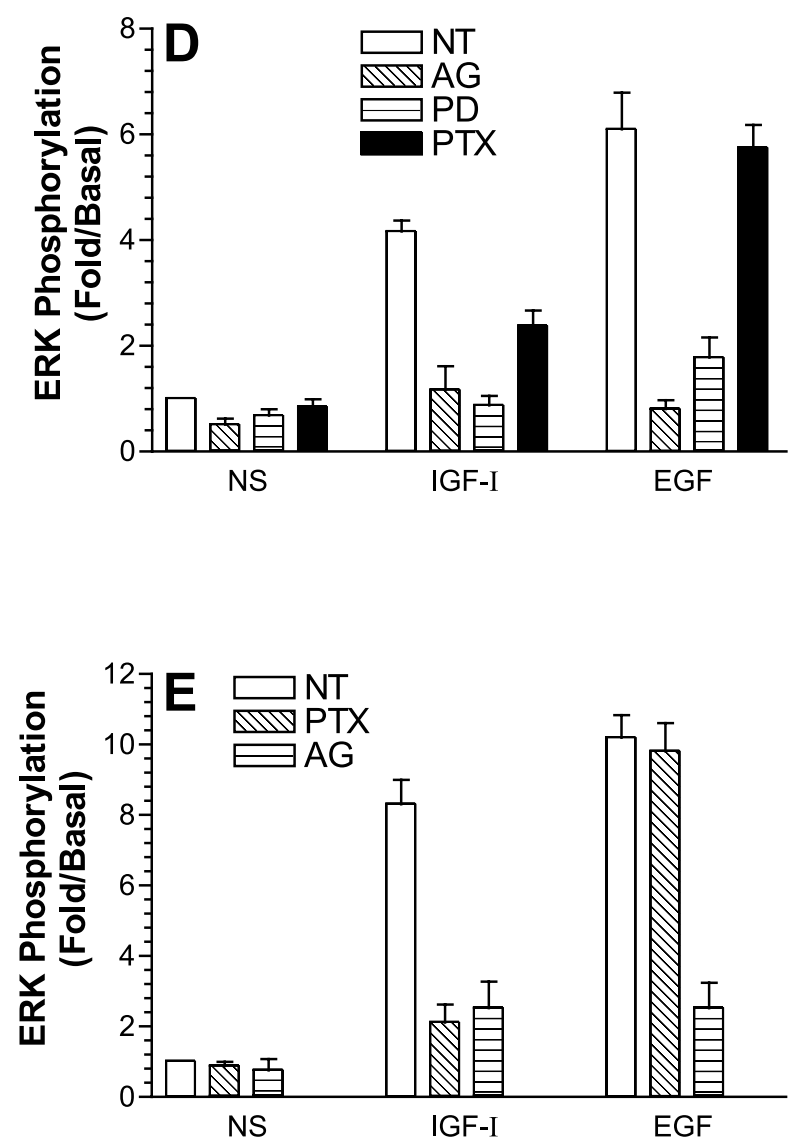

Figure 4 Effect of PTX and AG1478 on IGF-I-induced activation of ERK. (A) Effect of EGFR inhibitor tyrphostin AG1478 on IGF-I-induced ERK activation. Overnight serum-starved (NS) DU145 cells were pretreated with AG1478 (AG; $250 \mathrm{nM}$ ) or PD098059 (PD; $1 \mu \mathrm{M})$ for $30 \mathrm{~min}$ prior to simulation with IGF-I $(20 \mathrm{ng} / \mathrm{ml})$ or EGF $(10 \mathrm{ng} / \mathrm{ml})$ for 5 min. (B) Effect of Gi inhibitor PTX on IGF-I-induced ERK activation. DU145 cells were pre-incubated with PTX $(100 \mathrm{ng} / \mathrm{ml})$ during the overnight starvation period, or PD098059 for 30 min prior to stimulation with IGF-I or EGF for 5 min. (C) Effect of AG1478 and PTX on the IGF-I-mediated ERK phosphorylation (P-ERK) in P69SV40T cells. Cells were incubated in serum-free medium for 3 days, then treated with AG1478 or PTX inhibitors, as above. Cells were stimulated for $5 \mathrm{~min}$ with either IGF-I $(20 \mathrm{ng} / \mathrm{ml})$ or EGF $(10 \mathrm{ng} / \mathrm{ml})$. In all cases, stimulated cells were directly lysed in Laemmli sample buffer and analyzed for ERK activation by immunoblotting with anti-phospho ERK antibodies. Filters were stripped of immunoglobulins and reblotted for ERK 2 expression using anti-ERK 2 IgG, to ensure equal loading of proteins in all lanes. Representative immunoblots are shown. The average results of three independent experiments are shown for the (D) DU145 and (E) P69SV40T cells. nt, not treated.

proteins in the IGF-I-induced ERK activation. We tested whether $\mathrm{Gi} / \mathrm{o}$ proteins are functionally important in the IGF-I-induced prostate cell growth. Figure 5 shows that the P69SV40T cells proliferated following IGF-I treatment, and this proliferative response was inhibited by treatment with PTX. The inhibitory effect of PTX on DU145 cell proliferation was less pronounced; about half of that seen in the P69SV40T cells. These data demonstrated the involvement of $\mathrm{Gi} / \mathrm{o}$ proteins in the IGF-I-regulated growth of human prostate cells.

\section{Discussion}

In the present study, we characterized a mitogenic signal transduction pathway of IGF-IR in tumorigenic and non-tumorigenic human prostate cells. 


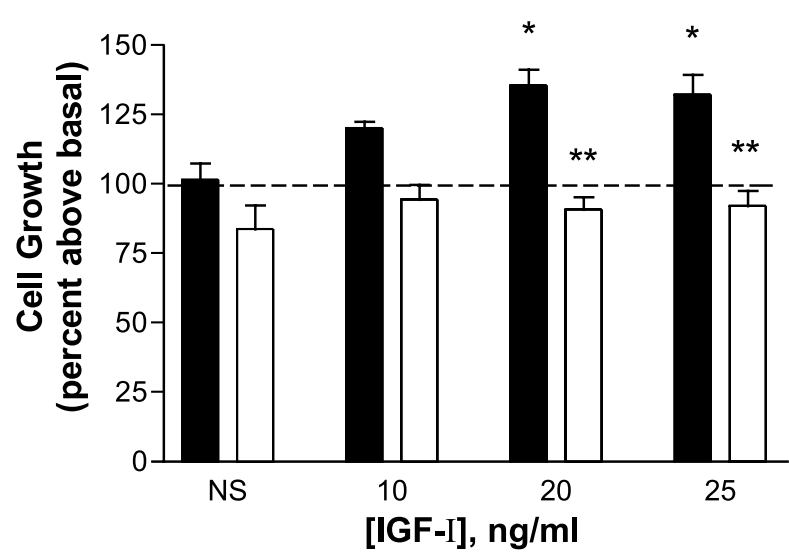

Figure 5 Effect of PTX on IGF-I-induced prostate cell growth. P69SV40T cells were incubated in serum-free medium and stimulated with increasing concentrations of IGF-I in the presence (open bars) or absence (solid bars) of PTX (100 ng/ml). Cell growth was determined using the WST-1 reagent, as described in Fig. 1. Data are presented as means \pm S.D. ${ }^{\star} P<0.05$ compared with control value; ${ }^{\star \star} P<0.01$ compared with IGF-I-induced values.

Our results showed that stimulation of endogenous IGF-IRs in these cells evokes similar mechanisms for ERK activation and cell growth. Importantly, we demonstrated that the IGF-I-regulated prostate cell growth involves $\mathrm{Gi} /$ o proteins.

The IGF-I likely plays an important role in prostate carcinogenesis. Men with prostate cancer express elevated levels of circulating IGF-I (Chan et al. 1998), and overexpression of IGF-I in prostate epithelial cells results in prostate cancer in a mouse model system (DiGiovanni et al. 2000). In nonprostate cells, new evidence implicates $G$ proteins in IGF-IR signaling. However, the physiologic significance of the $G$ proteins to IGF-IR signaling appears to be dependent on the type of target cell. For example, treatment with PTX was shown to exert contradictory effects on IGF-I-regulated signaling; it inhibits the IGF-I-induced mobilization of intracellular $\mathrm{Ca}^{2+}$ in NIH3T3 cells and chondrocytes (Kanzaki et al. 1997, Poiraudeau et al. 1997), activation of phagocytosis in neutrophils (Jin et al. 1993), and proliferation of myoblasts (Sarbassov et al. 1997). In contrast, PTX treatment fails to affect other IGF-I-regulated signaling pathways, including DNA synthesis in osteosarcoma and normal rat kidney epithelial cells (Linder et al. 1994, Siebler et al. 1996), and mobility of melanoma cells (Stracke et al. 1988). Our data demonstrated that PTX attenuates the IGF-Iregulated ERK activation and growth of human prostate epithelial cells.

The evidence available suggests the existence of at least two possible mechanisms to explain how the IGF-IR activates the Gi/o proteins. First, IGF-IR, similar to a canonical GPCR, could directly interact with and activate the $G$ proteins (Sanchez-Margalet et al. 1999, Hallak et al. 2000, Kuemmerle \& Murthy 2001). Stimulated insulin receptor, an IGF-IR family member, was reported to catalytically activate $\mathrm{Gi} / \mathrm{o}$ proteins in a manner similar to GPCRs in rat hepatoma cells (SanchezMargalet et al. 1999). Further, Gi/o proteins were recently shown to be constitutively associated with the IGF-IR in neuronal cells (Hallak et al. 2000), and stimulation with IGF-I promotes the release of G $\beta \gamma$ subunits from IGF-IR in normal human intestinal smooth muscle cells (Kuemmerle \& Murthy 2001). Alternatively, the IGF-IR could activate $\mathrm{G}$ proteins via a bridging GPCR. Human embryonic kidney-293 cell migration towards platelet-derived growth factor (PDGF) was mediated by the release of sphingosine 1-phosphate and consequent activation of its cognate GPCR, endothelial differentiation gene 1 (EDG-1) (Hobson et al. 2001). It is not clear at present whether these seemingly different possibilities stem from distinct mechanisms of action or successive steps in a common signaling pathway. Further, since the contribution of $\mathrm{Gi} / \mathrm{o}$ proteins to IGF-IR-regulated signaling is cell-type specific, it remains to be determined how PTX inhibits the IGF-I signaling in human prostate cells. Interestingly, we have preliminary data to suggest that stimulation of the prostate cells with IGF-I induces secretion of LPA, which promotes a Gi-mediated ERK activation and prostate cell growth (Kue \& Daaka 2000, Kue et al. 2002).

In addition to the requirement for $\mathrm{Gi}$ /o proteins in IGF-IR-regulated ERK activation and prostate cell growth, we observed that 'transactivation' of EGFR by IGF-I is also necessary for IGF-IR signaling. Transactivation refers to the process of EGFR phosphorylation on tyrosine residues in the absence of exogenously added EGF. The mechanism by which IGF-IR transactivates the EGFR in human prostate cells is not known. In COS-7 cells, IGF-I induces the tyrosine phosphorylation of EGFR via ectodomain shedding of heparin-bound (HB)-EGF in a mechanism that employs matrix 
metalloproteinases (MMP) (Roudabush et al. 2000). Pharmacologic inhibition of MMP activation by 1,10-phenanthroline prevents the IGF-I-regulated HB-EGF secretion, EGFR tyrosine phosphorylation, and ERK activation (Roudabush et al. 2000). These data exactly parallel results obtained from the studies of GPCR-regulated transactivation of EGFR (Raj et al. 2002, Kue et al. 2002). However, the EGFR was also reported to become transactivated by heterodimerization with other receptor types. For example, stimulation of rat aortic smooth muscle cells with PDGF ( $\mathrm{Li}$ et al. 2000), COS-7 cells with isoproterenol (Maudsley et al. 2000), and androgen-dependent LNCaP prostate cancer cells with interleukin 6 (Qiu et al. 1998) induces the dimerization of EGFR with, respectively, the PDGF receptor, $\beta 2$ adrenergic receptor, and interleukin 6 receptor. In all cases, existence of the heteroreceptor complex was required for the agonist-induced ERK activation. Our data showed that activated IGF-IR forms complex with EGFR. Taken together, these data suggest that stimulation of human prostate cells with IGF-I induces mitogenic signaling, possibly as a consequence of forming heterodimeric complexes between endogenous IGF-IR and EGFR.

In summary, stimulation of endogenous IGF-IR contributes to the growth of human prostate epithelial cells. Our observations that Gi/o proteins participate in the IGF-IR-induced mitogenic signaling and growth of the prostate cells suggested that the $\mathrm{Gi} / \mathrm{o}$ proteins could represent an important target for treatment of human prostate cancer. Thus, inhibition of $\mathrm{Gi} /$ o protein signaling may be of therapeutic value for the successful treatment of prostate carcinoma.

\section{Acknowledgements}

This work was supported by grants AG17952 and DK60917 from the National Institutes of Health to Y D. We thank Ms A Finney for technical assistance and Ms J House for secretarial assistance.

\section{References}

Barki-Harrington L, Bookout AL, Wang G, Lamb ME, Leeb-Lundberg LM \& Daaka Y 2003 Requirement for direct cross-talk between $\mathrm{B} 1$ and $\mathrm{B} 2$ kinin receptors for the proliferation of androgen-insensitive prostate cancer PC3 cells. Biochemical fournal 371 581-587.
Barki-Harrington L \& Daaka Y 2001 Bradykinin induced mitogenesis of androgen independent prostate cancer cells. Foumal of Urology 165 2121-2125.

Blumer JB \& Lanier SM 2003 Accessory proteins for G protein-signaling systems: activators of $\mathrm{G}$ protein signaling and other nonreceptor proteins influencing the activation state of $\mathrm{G}$ proteins. Receptors and Channels 9 195-204.

Bookout AL, Finney AE, Guo R, Peppel K, Koch WJ \& Daaka Y 2003 Targeting G $\beta \gamma$ signaling to inhibit prostate tumor formation and growth. Fournal of Biological Chemistry 278 37569-37573.

Bostwick DG, Shan A, Qian J, Darson M, Maihle NJ, Jenkins RB \& Cheng L 1998 Independent origin of multiple foci of prostatic intraepithelial neoplasia: comparison with matched foci of prostate carcinoma. Cancer 83 1995-2002.

Chan JM, Stampfer MJ, Giovannucci E, Gann PH, Ma J, Wilkinson P, Hennekens CH \& Pollak M 1998 Plasma insulin-like growth factor-I and prostate cancer risk: a prospective study. Science 279 563-566.

Daaka Y 2002 Mitogenic action of LPA in prostate. Biochimica et Biophysica Acta 1582 265-269.

DiGiovanni J, Kiguchi K, Frijhoff A, Wilker E, Bol DK, Beltran L, Moats S, Ramirez A, Jorcano J \& Conti C 2000 Deregulated expression of insulin-like growth factor 1 in prostate epithelium leads to neoplasia in transgenic mice. PNAS 97 3455-3460.

Djavan B, Waldert M, Seitz C \& Marberger M 2001 Insulin-like growth factors and prostate cancer. World Journal of Urology 19 225-233.

Franke TF, Kaplan DR \& Cantley LC 1997 PI3K: downstream AKTion blocks apoptosis. Cell $\mathbf{8 8} 435-437$.

Gioeli D, Mandell JW, Petroni GR, Frierson HF Jr \& Weber MJ 1999 Activation of mitogen-activated protein kinase associated with prostate cancer progression. Cancer Research 59 279-284.

Guo C, Luttrell LM \& Price DT 2000 Mitogenic signaling in androgen sensitive and insensitive prostate cancer cell lines. Fournal of Urology 163 1027-1032.

Hallak H, Seiler AE, Green JS, Ross BN \& Rubin R 2000 Association of heterotrimeric G(i) with the insulin-like growth factor-I receptor. Release of $\mathrm{G} \beta \gamma$ subunits upon receptor activation. Fournal of Biological Chemistry 275 2255-2258.

Hobson JP, Rosenfeldt HM, Barak LS, Olivera A, Poulton S, Caron MG, Milstien S \& Spiegel S 2001 Role of the sphingosine-1-phosphate receptor EDG-1 in PDGF-induced cell motility. Science 291 1800-1803.

Huggins C \& Hodges CV 1941 Studies on prostatic cancer. Cancer Research 1 293-297.

Jemal A, Murray T, Samuels A, Ghafoor A, Ward E \& Thun MJ 2003 Cancer statistics, 2003. CA: Cancer Fournal for Clinicians $\mathbf{5 3}$ $5-26$.

Jin GF, Guo YS, Ball C \& Houston CW 1993 Insulin-like growth factors enhance phagocytosis by human neutrophils in vitro. Regulatory Peptides 49 125-131.

Kanzaki M, Nie L, Shibata H \& Kojima I 1997 Activation of a calcium-permeable cation channel CD20 expressed in Balb/c 3T3 cells by insulin-like growth factor-I. Fournal of Biological Chemistry 27249644969.

Kue PF \& Daaka Y 2000 Essential role for G proteins in prostate cancer cell growth and signaling. Fournal of Urology $\mathbf{1 6 4}$ 2162-2167.

Kue PF, Taub JS, Harrington LB, Polakiewicz RD, Ullrich A \& Daaka Y 2002 Lysophosphatidic acid-regulated mitogenic ERK signaling in androgen-insensitive prostate cancer PC-3 cells. International Fournal of Cancer 102 572-579.

Kuemmerle JF \& Murthy KS 2001 Coupling of the insulin-like growth factor-I receptor tyrosine kinase to Gi2 in human intestinal smooth muscle: G $\beta \gamma$-dependent mitogen-activated protein kinase activation and growth. Fournal of Biological Chemistry $2767187-7194$ 
LeRoith D \& Roberts CT Jr 2003 The insulin-like growth factor system and cancer. Cancer Letters 195 127-137.

Li J, Kim YN \& Bertics PJ 2000 Platelet-derived growth factor-stimulated migration of murine fibroblasts is associated with epidermal growth factor receptor expression and tyrosine phosphorylation. Fournal of Biological Chemistry 275 2951-2958.

Linder B, Harris S, Eisen A \& Nissley P 1994 Evidence against roles for pertussis toxin sensitive $\mathrm{G}$ proteins or diacylglycerol generation in insulin-like growth factor-1 stimulated DNA synthesis in MG-63 osteosarcoma cells. Molecular and Cellular Endocrinology 105 111-118.

Maudsley S, Pierce KL, Zamah AM, Miller WE, Ahn S, Daaka Y, Lefkowitz RJ \& Luttrell LM 2000 The $\beta 2$-adrenergic receptor mediates extracellular signal-regulated kinase activation via assembly of a multi-receptor complex with the epidermal growth factor receptor. Fournal of Biological Chemistry $\mathbf{2 7 5}$ 9572-9580.

Nelson WG, De Marzo AM \& Isaacs WB 2003 Prostate cancer. New England Fournal of Medicine 349 366-381.

Plymate SR, Tennant M, Birnbaum RS, Thrasher JB, Chatta G \& Ware JL 1996 The effect on the insulin-like growth factor system in human prostate epithelial cells of immortalization and transformation by simian virus-40 $\mathrm{T}$ antigen. Fournal of Clinical Endocrinology and Metabolism 81 3709-3716.

Poiraudeau S, Lieberherr M, Kergosie N \& Corvol MT 1997 Different mechanisms are involved in intracellular calcium increase by insulin-like growth factors 1 and 2 in articular chondrocytes: voltage-gated calcium channels, and/or phospholipase $\mathrm{C}$ coupled to a pertussis-sensitive $\mathrm{G}$ protein. Fournal of Cellular Biochemistry $64414-422$.

Qiu Y, Ravi L \& Kung HJ 1998 Requirement of ErbB2 for signaling by interleukin-6 in prostate carcinoma cells. Nature 393 83-85.

Raj GV, Barki-Harrington L, Kue PF \& Daaka Y 2002 Guanosine phosphate binding protein coupled receptors in prostate cancer. Fournal of Urology 167 1458-1463.
Roudabush FL, Pierce KL, Maudsley S, Khan KD \& Luttrell LM 2000 Transactivation of the EGF receptor mediates IGF-1-stimulated shc phosphorylation and ERK1/2 activation in COS-7 cells. Fournal of Biological Chemistry 275 22583-22589.

Sanchez-Margalet V, Gonzalez-Yanes C, Santos-Alvarez J \& Najib S 1999 Insulin activates $\mathrm{G} \alpha \mathrm{il}, 2$ protein in rat hepatoma (HTC) cell membranes. Cellular and Molecular Life Sciences 55 142-147.

Sarbassov DD, Jones LG \& Peterson CA 1997 Extracellular signal-regulated kinase-1 and -2 respond differently to mitogenic and differentiative signaling pathways in myoblasts. Molecular Endocrinology 11 2038-2047.

Sasaoka T, Rose DW, Jhun BH, Saltiel AR, Draznin B \& Olefsky JM 1994 Evidence for a functional role of Shc proteins in mitogenic signaling induced by insulin, insulin-like growth factor-1, and epidermal growth factor. Fournal of Biological Chemistry 269 13689-13694.

Siebler T, Kiess W, Linder B, Kessler U, Schwarz HP \& Nissley SP 1996 Pertussis toxin sensitive G-proteins are not involved in the mitogenic signaling pathway of insulin-like growth factor-I in normal rat kidney epithelial (NRKE) cells. Regulatory Peptides 62 65-71.

Stracke ML, Kohn EC, Aznavoorian SA, Wilson LL, Salomon D, Krutzsch HC, Liotta LA \& Schiffmann E 1988 Insulin-like growth factors stimulate chemotaxis in human melanoma cells. Biochemical and Biophysical Research Communications 153 1076-1083.

Yang L, Camoratto AM, Baffy G, Raj S, Manning DR \& Williamson JR 1993 Epidermal growth factor-mediated signaling of $\mathrm{G}(\mathrm{i})$-protein to activation of phospholipases in rat-cultured hepatocytes. Fournal of Biological Chemistry 268 3739-3746.

Zeng H, Zhao D \& Mukhopadhyay D 2002 Flt-1-mediated down-regulation of endothelial cell proliferation through pertussis toxin-sensitive $\mathrm{G}$ proteins, $\beta \gamma$ subunits, small GTPase CDC42, and partly by Rac-1. Fournal of Biological Chemistry 277 4003-4009.

Received 18 March 2004 Accepted 29 April 2004 